\title{
PROCESSES OF CHANGE ASSOCIATED WITH THE FRUIT AND VEGETABLE CONSUMPTION ACROSS STAGES OF CHANGE IN WOMEN- APPLICATION OF TRANSTHEORETICAL MODEL
}

\author{
Mehdi Khezeli', Ali Ramezankhani², Abbas Aghaei ${ }^{3}$,Arman Latifi ${ }^{4}$, Hadi Darvishi5, Mohammad-Reza Yousefi ${ }^{6}$ \\ 1PhD, Department of Health Education and Health Promotion, School of Health, Kermanshah University of Medical Sciences, \\ Kermanshah, Iran. \\ 2Professor, Department of Public Health, School of Health, Shahid Beheshti University of Medical Sciences, Tehran, Iran. \\ ${ }^{3}$ PhD Candidate, Clinical Research Development Centre, Imam Khomeini Hospital, Kermanshah University of Medical Sciences, \\ Kermanshah, Iran. \\ ${ }^{4}$ Assistant Professor, Department of Public Health, Maragheh University of Medical Sciences, Maragheh, Iran. \\ ${ }_{5}^{5}$ M.Sc, Health Network of Gilan-e-Gharb, Kermanshah University of Medical Sciences, Kermanshah, Iran. \\ ${ }_{6}^{6}$ M.Sc, Health Network of Gilan-e-Gharb, Kermanshah University of Medical Sciences, Kermanshah, Iran.
}

\section{ABSTRACT}

\section{BACKGROUND}

Consumption of fruits and vegetables is associated with the reduction of many chronic diseases. Transtheoretical model is one of the most common models used for studies on nutrition. The objective of this study is to evaluate the processes of change across stages of change for fruits and vegetables consumption.

\section{MATERIALS AND METHODS}

600 literate women of Gilan-e-Gharb city (a west part of Iran) who were selected by random sampling method participated in this cross-sectional study. Data gathering tools was a questionnaire that consisted of 30 questions which included demographic (n= 5), stages of change $(n=5)$ and processes of change $(n=20)$ as well as 24 hours recall questionnaire for fruits and vegetables consumption. We assessed the internal consistency questions using Cronbach's Alpha and validity by S-CVI.

Statistical analysis used: Data were analysed by SPSS 19 using the T-test, ANOVA and Chi-square.

\section{RESULTS}

The majority of subjects (89.5\%) belonged to the passive stages of change (pre-contemplation, contemplation and preparation) and only 10.5 percent were in active stages (action and maintenance). Average daily consumption of fruits and vegetables was 3.4 \pm 0.96 servings, which was lowest in pre-contemplators and increased until the maintenance stage $(\mathrm{p}<.001)$. Mean score of cognitive and behavioural processes were higher in maintenance stage and lower in pre-contemplation stage.

\section{CONCLUSION}

Given the important role of the cognitive and behavioural processes in promoting people from passive stages to active stages of change, we suggest implementation of these processes by using appropriate strategies in educational intervention for promoting consumption of fruits and vegetables.

\section{KEYWORDS}

Fruit, Processes of Change, TTM, Vegetable.

HOW TO CITE THIS ARTICLE: Khezeli M, Ramezankhani A, Aghaei A, et al. Processes of change associated with the fruit and vegetable consumption across stages of change in women- application of transtheoretical model. J. Evolution Med. Dent. Sci. 2017;6(87):5991-5996, DOI: 10.14260/jemds/2017/1303

\begin{abstract}
BACKGROUND
Consumption of fruits and vegetables is associated with the reduction of many chronic diseases such as heart disease, stroke, hypertension, diabetes and some of cancers.[1,2] Inadequate levels of fruits and vegetables is one of the important modifiable risk factors that contribute to the increasing global burden of chronic diseases. ${ }^{[3]}$ According to the World Health Organisation (WHO) recommendation, women should consume at least $400 \mathrm{~g}$ of fruits and
\end{abstract}

'Financial or Other Competing Interest': None.

Submission 24-09-2017, Peer Review 18-10-2017,

Acceptance 24-10-2017, Published 30-10-2017.

Corresponding Author:

Mehdi Khezeli,

Department of Health Education and

Health Promotion, School of Health,

Kermanshah University of Medical Sciences,

Kermanshah, Iran.

E-mail: khezelimehdi@yahoo.com

DOI: $10.14260 /$ jemds/2017/1303

\section{(c) $($ ) $\odot$}

vegetables per day and this value should be approximately 7 percent of daily calorie intake.[4]

Limited studies on the consumption of fruit and vegetable in Kermanshah province (the west part of Iran) indicated that fruit and vegetable intake is lower than nutritional recommendations. ${ }^{[5-7]}$ Even when there is no difficulty to access and provision of fruits and vegetables, some people have insufficient consumption. Therefore, it seems that the psychological reasons can explain this issue.

Transtheoretical model (TTM) is one of the most popular models of health education and health promotion, which has been recognised as one of the methods to identify and change the diet, especially for fruits and vegetables.[8,9] TTM with the integration of processes of change in the stages of change tries to explain the psychosocial reasons of adopting or changing behaviour.[8] The core construct of this model is stages of change according to which when people are going to adopt or change a behaviour passes through a series of 
predictable stages including pre-contemplation, contemplation, preparation, action and maintenance.[10]

The second construct of TTM is processes of change and include strategies that people use to move through the stages of change.[9] These processes were divided into two categories: the first group are the experimental processes (cognitive processes) which refer to experiments that emphasise on the thoughts, emotions and cognitive experiences and must be existing in the early stages of change including consciousness raising, dramatic relief, selfreevaluation, environmental re-evaluation and social liberation. The second group are behavioural processes which focused on behaviours and reinforcement factors and often used in the action and maintenance stages including helping relationship, self-liberation, counter conditioning, stimulus control and reinforcement management.[8,11,12] Integration of the stages of behaviour change with the processes of change helps us to understand when and how changes occur.[13] Hence, the present study was conducted to investigate the processes of change across stages of change associated with the consumption of fruits and vegetables in the literate women of Gilan-e-Gharb city (the Kurdish part of Kermanshah province; located in the west of Iran). Women were selected as the target group for this study, because they have an important role in maintaining the health of children and other family members as mothers as well as comprise about half of the population in the community.[14]

\section{MATERIALS AND METHODS}

This cross-sectional study was conducted with participation of 600 women aged 18 - 59 years in a Kurdish urban population under the coverage of health centre of Gilan-eGharb city.

Inclusion criteria consisted of the marriage, ability to read and write Persian language, residing in the Gilan-e-Gharb city as well as voluntary consent to participate in research. We excluded women who had disease or condition that requires contraindications or low consumption of fruits and vegetables. Participants were selected by systematic random sampling method in February and March of 2015. After explaining the purpose of research and ensuring the confidentiality of information, the informed consent form was obtained from individuals and then they completed questionnaires about 30 minutes.

\section{Measures}

Data gathering tool in this study was a four-part questionnaire, which was completed anonymously by the participants. Demographic questions located in the first section consisted of age, job, education, number of children and number of family members. The second part consisted of five questions related to the stages of change for fruit and vegetable consumption according to which individuals were placed in one of five stages including pre-contemplation, contemplation, preparation, action and maintenance. By default people in the pre-contemplation, contemplation and preparation stages consume less than five servings of fruits and vegetables per day and in action and maintenance stages consume more than five servings per day. The third part consisted of twenty questions, related to processes of behaviour change for fruit and vegetable consumption which were allocated two questions for each process (Table 1). Participants were asked to rate using a 5-point Likert scale (e.g. 1= "strongly disagree," 5= "strongly agree") for 20 items. Finally, we used the 24-hour recall standard questionnaire to assess the consumption of fruits and vegetables.

Panel of experts approved Content Validity Index (CVI) and Content Validity Ratio (CVR) of items. The questionnaire was represented to 60 women to assess the test-retest reliability after two weeks that the correlation between test and retest was 0.92 . In addition, we assessed the internal consistency of process of changing questions using Cronbach's Alpha, which was 0.73. Data analysed by Statistical Package for Social Sciences (SPSS) version 19 using Central indicators, Chi-square, Independent T-Test and ANOVA.

\section{RESULTS}

In total, 600 women participated in the study. The subjects' mean age was $33.16( \pm 7.6)$ years. Average number of household members was less than four people $(3.76, \mathrm{SD}=$ 1.24). As shown in Table 2, the majority of the subjects were housewives and had under high school diploma education. More details about demographic characteristics of the subjects were presented in Table 2 .

Table 3 shows average daily consumption of fruits and vegetables in the subjects, which was $3.4 \pm 0.96$ servings per day. The consumption was lowest in precontemplators and increased to maintenance stage $(\mathrm{P}<.001)$.

Based on the results showed in Figure 1, the majority of women $(89.5 \%)$ were in passive stages of change for consumption of fruits and vegetables and only 10.5 percent were in the active stages (action and maintenance).

Table 3 shows that mean score of cognitive processes in the maintenance stage is significantly more than other stages and in precontemplators was significantly less than other stages $(\mathrm{p}<0.001)$. The post-hoc test (Tukey) showed that there was no significant difference between mean score of cognitive processes in action stage with preparation and contemplation stages. In addition, mean score of behavioural processes from precontemplation to maintenance stage had increasing trend and post-hoc test (Tukey) showed that mean score of these processes in the maintenance stage was higher than other stages as well as in action and preparation, and contemplation stages were more than precontemplation stage.

According to the results showed in Table 4, mean scores of cognitive processes (except for the process of consciousness rising) and behavioural processes in the maintenance stage is significantly more than precontemplation stage. About the consciousness raising process, significant difference between precontemplation and maintenance stages was not found. Results of one-way ANOVA showed that mean score of each of the processes at different stages had significant differences and about dramatic relief, self-re-evaluation, reinforcement management, social liberation and environment reevaluation significantly had increased from passive stages to active stages. 


\begin{tabular}{|c|c|c|}
\hline $\begin{array}{l}\text { Process } \\
\text { Name }\end{array}$ & $\begin{array}{l}\text { Theoretical } \\
\text { Definition }\end{array}$ & $\begin{array}{c}\text { Question } \\
\text { Sample }\end{array}$ \\
\hline \multicolumn{3}{|c|}{ Cognitive (Experimental) Processes } \\
\hline $\begin{array}{l}\text { Conscious- } \\
\text { ness raising }\end{array}$ & $\begin{array}{c}\text { Increasing awareness } \\
\text { via information, } \\
\text { education and } \\
\text { personal feedback } \\
\text { about the healthy } \\
\text { behaviour }\end{array}$ & $\begin{array}{c}\text { I am looking for } \\
\text { information through } \\
\text { the media and } \\
\text { advertising about the } \\
\text { benefits of fruits and } \\
\text { vegetables }\end{array}$ \\
\hline $\begin{array}{c}\text { Dramatic } \\
\text { relief }\end{array}$ & $\begin{array}{c}\text { Experiencing the } \\
\text { negative emotions } \\
\text { (fear, anxiety, worry) } \\
\text { that go along with } \\
\text { particular } \\
\text { behavioural risks }\end{array}$ & $\begin{array}{l}\text { I think to the warnings } \\
\text { about low consumption } \\
\text { of fruits and vegetables }\end{array}$ \\
\hline $\begin{array}{c}\text { Self- } \\
\text { reevaluation }\end{array}$ & $\begin{array}{l}\text { Assessment of one's } \\
\text { self-image with and } \\
\text { without a particular } \\
\text { unhealthy habit }\end{array}$ & $\begin{array}{c}\text { I blame myself when I } \\
\text { do not consume enough } \\
\text { fruits and vegetables }\end{array}$ \\
\hline $\begin{array}{l}\text { Environ- } \\
\text { mental re- } \\
\text { evaluation }\end{array}$ & $\begin{array}{l}\text { How the presence or } \\
\text { absence of a personal } \\
\text { habit affects one's } \\
\text { social environment }\end{array}$ & $\begin{array}{l}\text { I am concerned to this } \\
\text { point that the lack of } \\
\text { fruits and vegetables in } \\
\text { my food plan has a } \\
\text { negative impact on my } \\
\text { family members }\end{array}$ \\
\hline $\begin{array}{c}\text { Social } \\
\text { liberation }\end{array}$ & $\begin{array}{c}\text { Society is more } \\
\text { supportive of the } \\
\text { healthy behaviour }\end{array}$ & $\begin{array}{l}\text { Today, women have } \\
\text { more attention to the } \\
\text { consumption of fruits } \\
\text { and vegetables }\end{array}$ \\
\hline \multicolumn{3}{|c|}{ Behavioural Processes } \\
\hline $\begin{array}{l}\text { Helping } \\
\text { relationship }\end{array}$ & $\begin{array}{l}\text { Seeking and using } \\
\text { social support for the } \\
\text { recommended } \\
\text { behaviour change }\end{array}$ & $\begin{array}{l}\text { I have people who } \\
\text { remind me about the } \\
\text { consumption of fruits } \\
\text { and vegetables }\end{array}$ \\
\hline Self-liberation & $\begin{array}{c}\text { Believing in one's } \\
\text { ability to change and } \\
\text { making commitments } \\
\text { and recommitments } \\
\text { to act on that belief }\end{array}$ & $\begin{array}{l}\text { I say to myself that if I } \\
\text { want I can eat more } \\
\text { fruits and vegetables }\end{array}$ \\
\hline $\begin{array}{c}\text { Counter } \\
\text { conditioning }\end{array}$ & $\begin{array}{c}\text { Substitution of } \\
\text { recommended } \\
\text { alternative behaviours } \\
\text { and cognitions for the } \\
\text { problem behaviour }\end{array}$ & $\begin{array}{c}\text { Instead of eating junk } \\
\text { food, I prefer to eat } \\
\text { fruits and vegetables as } \\
\text { snacks }\end{array}$ \\
\hline Stimulus & Using reminders and & I place something \\
\hline
\end{tabular}

\begin{tabular}{|c|c|c|}
\hline control & $\begin{array}{c}\text { cues that encourage } \\
\text { healthy behaviour as } \\
\text { substitutes for those } \\
\text { that encourage the } \\
\text { unhealthy behaviour }\end{array}$ & $\begin{array}{c}\text { house to remind me } \\
\text { that I should eat more } \\
\text { fruits and vegetables }\end{array}$ \\
\hline Re- & $\begin{array}{c}\text { Increasing the } \\
\text { rewards for the } \\
\text { positive behaviour } \\
\text { change and } \\
\text { inforcement } \\
\text { management } \\
\text { decreasing the } \\
\text { rewards of the } \\
\text { problem behaviour }\end{array}$ & $\begin{array}{c}\text { If I take more fruits and } \\
\text { vegetables, I am } \\
\text { encouraged by others }\end{array}$ \\
\hline \multicolumn{2}{|c|}{ Table 1. Processes of Behaviour Change based on TTM } \\
\hline
\end{tabular}

\begin{tabular}{|c|c|}
\hline Characteristic & No. (\%) of Participants \\
\hline \multicolumn{2}{|l|}{ Education } \\
\hline$<12$ & $272(45.3)$ \\
\hline$=12$ & $230(38.3)$ \\
\hline$>12$ & $98(16.4)$ \\
\hline \multicolumn{2}{|l|}{ Age } \\
\hline $18-34$ & $325(54.2)$ \\
\hline $35-49$ & $254(42.3)$ \\
\hline 50 and above & $21(3.5)$ \\
\hline \multicolumn{2}{|l|}{ Number of Children } \\
\hline 0 & $113(18.8)$ \\
\hline 1 & $114(19)$ \\
\hline 2 & $241(40.2)$ \\
\hline 3 and above & $132(22)$ \\
\hline \multicolumn{2}{|l|}{ Job } \\
\hline Housewife & $534(89)$ \\
\hline Employee & $66(11)$ \\
\hline \multicolumn{2}{|c|}{ Table 2. Description of the 600 Study Participants } \\
\hline
\end{tabular}

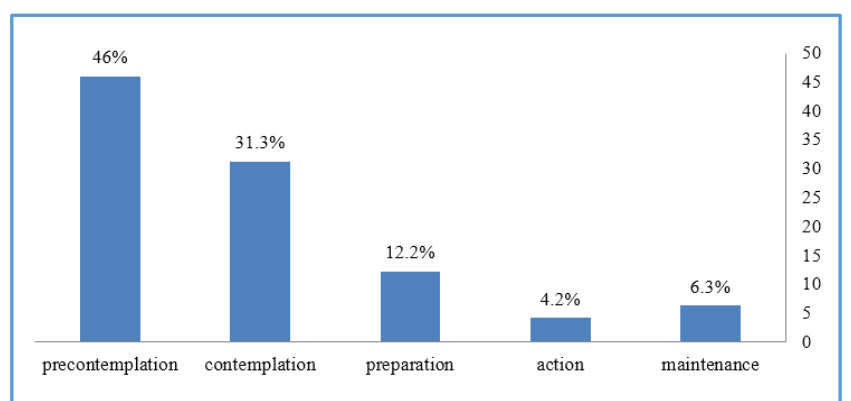

Figure 1. Distribution of the Subjects across Stages of Change of the Fruits and Vegetables Consumption

\begin{tabular}{|c|c|c|c|c|c|c|c|}
\hline & \multicolumn{5}{|c|}{ Stages of Change } & \multirow[b]{2}{*}{ Total } & \multirow[b]{2}{*}{ Test } \\
\hline Variable & PC & $\mathbf{C}$ & $\mathbf{P}$ & $\mathbf{A}$ & $\mathbf{M}$ & & \\
\hline Experiential processes & $\begin{array}{l}39.87 \mathrm{a} \\
\pm 4.22\end{array}$ & $\begin{array}{l}41.30 \mathrm{~b} \\
\pm 3.24\end{array}$ & $\begin{array}{l}42.88 \mathrm{c} \\
\pm 2.94\end{array}$ & $\begin{array}{c}41.62 \mathrm{~b}, \mathrm{c} \\
\pm 3.0\end{array}$ & $\begin{array}{l}45.54 \mathrm{~d} \\
\pm 2.90\end{array}$ & $\begin{array}{l}41.12 \\
\pm 3.98\end{array}$ & $\begin{array}{l}F=26.64 \\
P<.001\end{array}$ \\
\hline Behavioural processes & $\begin{array}{c}34.44 \mathrm{a} \\
\pm 4.11\end{array}$ & $\begin{array}{c}36.47 \mathrm{~b} \\
\pm 4.16\end{array}$ & $\begin{array}{l}35.94 \mathrm{~b} \\
\pm 3.80\end{array}$ & $\begin{array}{l}37.09 \mathrm{~b} \\
\pm 5.29\end{array}$ & $\begin{array}{l}41.33 \mathrm{c} \\
\pm 3.10\end{array}$ & $\begin{array}{l}35.80 \\
\pm 4.42\end{array}$ & $\begin{array}{l}F=27.42 \\
P<.001\end{array}$ \\
\hline $\begin{array}{c}\text { Consumption } \\
\text { (Serving per day) }\end{array}$ & $\begin{array}{l}2.93 a \\
\pm 0.57 \\
\end{array}$ & $\begin{array}{l}3.29 \mathrm{~b} \\
\pm 0.54 \\
\end{array}$ & $\begin{array}{l}3.48 \mathrm{c} \\
\pm 0.44 \\
\end{array}$ & $\begin{array}{l}5.02 \mathrm{~d} \\
\pm 0.69 \\
\end{array}$ & $\begin{array}{l}5.95 \mathrm{e} \\
\pm 0.47\end{array}$ & $\begin{array}{c}3.40 \\
\pm 0.96 \\
\end{array}$ & $\begin{array}{c}\mathrm{F}=313.48 \\
\mathrm{P}<.001\end{array}$ \\
\hline
\end{tabular}

P indicates precontemplation, C- contemplation, P- preparation, A- action and M- maintenance. Means with differing superscript letters are significantly different at $\mathrm{p}<0.05$ by Tukey HSD post-hoc. 


\begin{tabular}{|c|c|c|c|c|c|c|c|}
\hline \multirow{2}{*}{ Variable } & \multicolumn{5}{|c|}{ Stages of Change } & \multirow{2}{*}{ Total } & \multirow{2}{*}{ Test } \\
\hline & PC & C & $\mathbf{P}$ & A & $\mathbf{M}$ & & \\
\hline Consciousness raising & $\begin{array}{r}8.50^{\mathrm{a}} \\
\pm 1.13\end{array}$ & $\begin{array}{l}8.75^{\mathrm{b}} \\
\pm 1.10\end{array}$ & $\begin{array}{l}9.30^{\mathrm{c}} \\
\pm 1.19\end{array}$ & $\begin{array}{c}9.03^{\mathrm{b}, \mathrm{c}} \\
\pm .60\end{array}$ & $\begin{array}{l}8.5^{\mathrm{a}, \mathrm{b}} \\
\pm .99\end{array}$ & $\begin{array}{c}8.70 \\
\pm 1.13\end{array}$ & $\begin{array}{c}\mathrm{F}=8.09 \\
\mathrm{P}<.001\end{array}$ \\
\hline Dramatic relief & $\begin{array}{r}7.78^{a} \\
\pm 1.45\end{array}$ & $\begin{array}{l}8.13^{b} \\
\pm .92\end{array}$ & $\begin{array}{c}8.27 \mathrm{~b} \\
\pm .79\end{array}$ & $\begin{array}{l}8.48^{\mathrm{b}, \mathrm{c}} \\
\pm 1.12\end{array}$ & $\begin{array}{l}8.90^{c} \\
\pm 1.19\end{array}$ & $\begin{array}{c}8.05 \\
\pm 1.24\end{array}$ & $\begin{aligned} F & =9.69 \\
P & <.001\end{aligned}$ \\
\hline Environment re-evaluation & $\begin{array}{l}7.56^{\mathrm{a}} \\
\pm 1.77\end{array}$ & $\begin{array}{c}7.88^{\mathrm{b}} \\
\pm 1.22\end{array}$ & $\begin{array}{l}8.01^{\mathrm{b}} \\
\pm .91\end{array}$ & $\begin{array}{l}8.33^{\mathrm{b}} \\
\pm 1.39\end{array}$ & $\begin{array}{l}9.51^{c} \\
\pm .64\end{array}$ & $\begin{array}{c}7.87 \\
\pm 1.53\end{array}$ & $\begin{array}{l}\mathrm{F}=16.72 \\
\mathrm{P}<.001\end{array}$ \\
\hline Self-re-evaluation & $\begin{array}{r}7.76^{\mathrm{a}} \\
\pm 1.38\end{array}$ & $\begin{array}{l}8.05^{\mathrm{b}} \\
\pm 1.23\end{array}$ & $\begin{array}{l}8.43^{\mathrm{c}} \\
\pm 1.30 \\
\end{array}$ & $\begin{array}{l}8.19 \mathrm{c} \\
\pm 1.20\end{array}$ & $\begin{array}{c}9.0^{\mathrm{d}} \\
\pm 1.45\end{array}$ & $\begin{array}{c}8.02 \\
\pm 1.36\end{array}$ & $\begin{aligned} F & =9.89 \\
P & <.001\end{aligned}$ \\
\hline Social liberation & $\begin{array}{r}8.24 \mathrm{~b} \\
\pm 1.35 \\
\end{array}$ & $\begin{array}{l}8.50^{c} \\
\pm 1.07 \\
\end{array}$ & $\begin{array}{l}8.84 \mathrm{~d} \\
\pm 1.26 \\
\end{array}$ & $\begin{array}{l}7.62^{\mathrm{a}} \\
\pm .60 \\
\end{array}$ & $\begin{array}{l}9.66^{\mathrm{e}} \\
\pm .80 \\
\end{array}$ & $\begin{array}{c}8.47 \\
\pm 1.27 \\
\end{array}$ & $\begin{array}{l}\mathrm{F}=16.37 \\
\mathrm{P}<.001\end{array}$ \\
\hline Self-liberation & $\begin{array}{r}7.47 \mathrm{a} \\
\pm 1.60\end{array}$ & $\begin{array}{l}7.56^{\mathrm{a}} \\
\pm 1.85\end{array}$ & $\begin{array}{l}7.51^{\mathrm{a}} \\
\pm 1.95\end{array}$ & $\begin{array}{l}8.33^{\mathrm{b}} \\
\pm 1.62\end{array}$ & $\begin{array}{l}8.46^{b} \\
\pm .85\end{array}$ & $\begin{array}{c}7.6 \\
\pm 1.71\end{array}$ & $\begin{array}{l}\mathrm{F}=9.74 \\
\mathrm{P}=.003\end{array}$ \\
\hline Counter conditioning & $\begin{array}{r}7.82^{\mathrm{a}} \\
\pm 1.61 \\
\end{array}$ & $\begin{array}{r}7.94^{\mathrm{a}} \\
\pm 2.15 \\
\end{array}$ & $\begin{array}{r}7.91^{\mathrm{a}} \\
\pm 2.11 \\
\end{array}$ & $\begin{array}{l}7.71^{\mathrm{a}} \\
\pm 2.24 \\
\end{array}$ & $\begin{array}{l}8.89 \mathrm{~b} \\
\pm 1.57 \\
\end{array}$ & $\begin{array}{c}7.93 \\
\pm 1.89 \\
\end{array}$ & $\begin{array}{l}\mathrm{F}=2.92 \\
\mathrm{P}=.021\end{array}$ \\
\hline Helping relationship & $\begin{array}{c}7.0^{\mathrm{a}} \\
\pm 1.63 \\
\end{array}$ & $\begin{array}{c}7.47^{\mathrm{b}} \\
\pm 1.50 \\
\end{array}$ & $\begin{array}{r}6.88^{\mathrm{a}} \\
\pm 1.62 \\
\end{array}$ & $\begin{array}{l}6.81^{\mathrm{a}, \mathrm{b}} \\
\pm 2.23 \\
\end{array}$ & $\begin{array}{r}7.9 \mathrm{c} \\
\pm 1.71 \\
\end{array}$ & $\begin{array}{c}7.19 \\
\pm 1.46 \\
\end{array}$ & $\begin{array}{l}F=5.20 \\
P<.001\end{array}$ \\
\hline Reinforcement management & $\begin{array}{r}5.43^{\mathrm{a}} \\
\pm 1.50\end{array}$ & $\begin{array}{l}6.01^{\mathrm{b}} \\
\pm 1.09\end{array}$ & $\begin{array}{l}6.09 \mathrm{~b} \\
\pm 1.46\end{array}$ & $\begin{array}{c}7.0^{\mathrm{c}} \\
\pm 2.01\end{array}$ & $\begin{array}{l}8.05^{\mathrm{d}} \\
\pm 1.67\end{array}$ & $\begin{array}{c}5.92 \\
\pm 1.57\end{array}$ & $\begin{array}{l}F=33.78 \\
P<.001\end{array}$ \\
\hline Stimulus control & $\begin{array}{r}6.72 \mathrm{a} \\
\pm 1.76\end{array}$ & $\begin{array}{l}7.47 \mathrm{~b}, \mathrm{c} \\
\pm 1.64\end{array}$ & $\begin{array}{l}7.56^{\mathrm{b}, \mathrm{c}} \\
\pm 1.55\end{array}$ & $\begin{array}{l}7.24^{\mathrm{a}, \mathrm{b}} \\
\pm 1.40\end{array}$ & $\begin{array}{l}8.02^{\mathrm{c}} \\
\pm 2.03\end{array}$ & $\begin{array}{c}7.16 \\
\pm 1.65\end{array}$ & $\begin{aligned} F & =9.59 \\
P & <.001\end{aligned}$ \\
\hline
\end{tabular}

\section{DISCUSSION}

In the present study, the majority of subjects were classified in passive stages of fruit and vegetable consumption and only 10.5 percent of participants were in action and maintenance stages (Active stages), which were consuming five and above servings of fruits and vegetables. In two similar studies, 65 and 66 percent of people were in active stages.[15,16] In other studies, people in active stages were more than in the present study.[12,17-19] It seems that lower education and higher household members are important factors in distribution of people across stages of change for fruit and vegetable consumption in this study.

Average consumption of fruit and vegetable from precontemplation to maintenance increased. This result confirms the hypothesis that consumption of fruits and vegetables in the stages of change is different and increase from lower stages (Passive stages) to higher stages (Active stages). This result is consistent with other similar studies.[12,15-17] Assessment of fruits and vegetables consumption based on Transtheoretical Model allows us to adjust our intervention both on the stages of change and on the number of consumed servings, and have a more targeted intervention.

In the present study, the mean score of cognitive (experimental) processes was different at the various stages of behaviour change. Mean score of this variable was higher in people at maintenance stage and lower in precontemplators. According to Di Carmo study, mean score of cognitive processes in maintenance, action and preparation stages was higher than contemplation and precontemplation. ${ }^{[20]}$ In other similar studies, cognitive processes in precontemplators were lower than other stages of behaviour change. ${ }^{[15,18]}$

Given to the special role processes of behaviour change in the transtheoretical model and in order to correct analysis of the processes, in the following we discuss each of the processes of change separately to examine their relationships, similarities and contradictions and possible reasons for them.
Consciousness raising process that refers to searching information and people's willingness to get news and information ${ }^{8,11]}$ was lower in precontemplators compared to contemplation, preparation and action stages. This result is consistent with the nature of precontemplators. According to Prochaska et al, precontemplators tend to avoid reading, talking or thinking about their high-risk behaviours.[21] Educational intervention for promoting people from precontemplation to contemplation stage, this process could be used effectively.

We measured the dramatic relief process with phrases related to attention and emotional arousal to warnings about low consumption of fruits and vegetables, so results showed that there were most emotional motivation in people at maintenance and lowest in precontemplators. This finding is similar to results from same studies.[15,20,22] These results confirmed that it is better the health messages be designed in a way that help people to leave the precontemplation stage, for example to some extent induce fear of the consequences due to the lack of consumption of fruits and vegetables (especially precontemplators). In this context Prochaska et al has introduced methods such as psychodrama, role-playing and media campaign. ${ }^{[8,21]}$

Environmental re-evaluation process was referred to the negative or positive impacts of adopting behaviour on family and social environment. [8] Mean score of this process in precontemplators was the lowest and in maintenance stage was the highest. According to Greene et al, precontemplators have reported the lowest adoption of this process and there was no significant difference between other stages.[15] In educational interventions based on Transtheoretical model, the three mentioned processes are important as targeted processes to promoting people from the precontemplation to the contemplation stage. ${ }^{[8,21]}$

Self-re-evaluation process in health education program is considered for promoting people from contemplation to preparation with methods such as enhanced self-concept, positive mental imagery and introducing healthy role models. ${ }^{[8,21]}$ The result of present study showed that this process was higher in preparation stage than contemplation. 
According to the defined relationships between the processes and stages of behaviour change,[8] the higher rate of self-re-evaluation in the preparation stage was compared to precontemplation and contemplation stages seems logical, because this process is the main strategy for the promotion of people from the contemplation to the preparation stage. People in preparation stage because of the motive and serious intention to adopt behaviour in the near future perhaps have a more positive image of the new behaviour and the results of this study indicated this issue.

The latest cognitive process, which was investigated in this study was social liberation. This process had the highest rate in the maintenance and lowest in the action stage. We were not able to offer the documented justification for this. However, we can say that individuals in action stage are in transition from adopting healthy behaviour to maintain it. More people at lower stage report they received less social support from other women related to consuming more fruits and vegetables.

The self-liberation as the first behavioural process was more in maintenance and action stages than precontemplation, contemplation and preparation. In a study by Greene, this process in precontemplators has been less than the other stages.[15] To promoting individuals from preparation to action stage, it is necessary to understand people's ability to change behaviour and enhance their selfefficacy. In addition, it is better that individuals have two or three options to choose as alternatives to test their ability to select the options.[15]

Counterconditioning process is applied, especially to promote the individuals from the action stage to maintenance. In this study, the mean score of this in maintenance phase was more than any other stages. The people who responded to the two questions showed that they used fruits and vegetables as snacks more than other people.

The third behavioural process was helping the relationship, which was highest in maintenance stages and lowest in precontemplation and preparation. Hildebrand et al have emphasised on important role of helping relationships and social support for increasing the consumption of fruits and vegetables.[18] In a study by Kim in relation to smoking cessation behaviour, among the process of behaviour change helping relationships has been introduced as the most important predictor of smoking cessation. [23]

Reinforcement management process as the most important behavioural processes is the most used process for promoting individual from the action stage to the maintenance.[21] In this study, the mean score of this process was the lowest compared to other processes, which represents low incentives and motives of the subjects. This process was also different in the various stages of change and in the active stage (Action and maintenance) was more than passive stages.

The last behavioural process that was investigated in this study was the process of stimulus control. This process refers to removing the unpleasant stimulus and adding favourable incentives to the environment.[8] In this study, decorating fruits and vegetables in beautiful containers for people pleasantly was studied as a form of stimulus control. The results showed that people in precontemplation and contemplation stages have paid less attention to this process compared to the other stages. People of these stages given that no real motivation to change behaviour and likely do not have a clear plan for behaviour change, fewer have adopted this behaviour process compared to the other people. Putting some stimulus at home (such as installing a poster in relation to the use or availability of fruits and vegetables in the refrigerator) is a form of stimulus control.

\section{CONCLUSION}

The study results showed that the average consumption of fruits and vegetables is not according to nutritional recommendations and is less than five servings per day. Hence, it is better to perform more researches on the causes and factors influencing the consumption of fruits and vegetables. From other important results of this study, we can refer to the significant differences between women's readiness to consumption of enough fruits and vegetables. The results showed the significant differences in the extent and manner of adopting the cognitive and behavioural processes by individuals in different stages of change. Both types of processes (Cognitive and behavioural) were more in active stages. Therefore, we suggest that a special attention be given to some practical strategies to upgrade the people from passive stages to the action and maintenance stages. Some of these cognitive strategies are included to provide information to raise awareness, emotional arousal for dramatic relief and pointing out the disadvantages of small amounts of fruits and vegetables in the diet of the family. In addition, some behavioural strategies include control of negative stimuli and provide positive incentives to promote the consumption of fruits and vegetables, replacement of fruits and vegetables instead of junk food and providing supportive relationships for people. These findings remind the health managers and health education professionals the necessity of attention to individual differences in health education programs. In other words, we must avoid the same training for different audiences, and design and implement targeted training programs according to the characteristics of the audiences.

\section{REFERENCES}

[1] USDA. Increasing fruit and vegetable consumption through the USDA nutrition assistance programs: a progress report. US Department of Agriculture Food and Nutrition Service/Office of Research, Nutrition, and Analysis Nutrition Services Staff. 2008.

[2] Pomerleau J, Lock K, Knai C, et al. Effectiveness of interventions and programs promoting fruit and vegetables intake. Geneva: WHO Press 2005.

[3] World Health Organization. Preventing chronic diseases: a vital investment: WHO global report. Geneva: WHO Press 2005.

[4] World Health Organization. Diet, nutrition and the prevention of chronic diseases: WHO Technical Report Series, No. 797. Geneva: WHO Press 1990.

[5] Khademi N, Mansoori F, Leghaei Z. Nutritional pattern and prevalence of cardiovascular disease in the Kermanshah province health centres staff. Karesalem 2009;3(9-10):83-8. 
[6] Delavari A, Alikhani S, Ala'edini F, et al. eds. Report of status of non-communicable diseases. Risk factors in Islamic Republic of Iran. Tehran: Seda 2005.

[7] Pasdar Y, Ghareh-Tapeh A, Pashaei T, et al. The nutritional status of elderly people covered by government centers in Kermanshah based on MNA and its correlation with biochemical markers in 2008. J Kermanshah Univ Med Sci 2011;15(3):178-85.

[8] Prochaska JO, Redding CA, Evers KE. Transtheoretical model and stages of change. In: Glanz K, Rimer KB, Viswanath K. Health behavior and health education: theory, research and practice. $4^{\text {th }}$ edn. San Francisco: Jossey-Bass 2008:97-121.

[9] Spencer L, Wharton C, Moyle S, et al. The transtheoretical model as applied to dietary behavior and outcomes. Nutr Res Rev 2007;20(1):46-73.

[10] Gorin SS. Models of health promotion. In: Gorin SS, Arnold J. eds. Health promotion in Action. San Francisco: Jossey-Bass 2006; p. 39.

[11] Sutton S. Stage theories of behavior change. In: Conner M, Norman P. eds. Predicting health behavior change. UK: Open University Press 2005:223-75.

[12] Henry H, Reimer K, Smith C, et al. Associations of decisional balance, processes of change and selfefficacy with stages of change for increased fruit and vegetable intake among low-income, African-American mothers. J Am Diet Assoc 2006;106(6):841-9.

[13] Ma J. Examination of the Transtheoretical Model (TTM) on fruit and vegetable intake (PhD Thesis): UMI, University of Nebraska: 2002.

[14] Rahimi OAR, Safaeian A, Modaresi ZH, et al. Effect of nutrition education intervention on nutritional Knowledge, Attitude and Practice (KAP) among female employees of Tabriz University of Medical Sciences. Med J Tabriz Uni Med Sci 2010;31(4):12-17.

[15] Greene GW, Fey-Yensan N, Padula C, et al. Differences in psychosocial variables by stage of change for fruits and vegetables in older adults. J Am Diet Assoc 2004;104(8):1236-1243.
[16] Van Duyn MAS, Heimendinger J, Estelle RC, et al. Use of the Transtheoretical Model of Change to Successfully Predicting Fruit and Vegetable Consumption. J Nutr Educ \& Behavior 1998;30(6):371-80.

[17] Glanz K, Patterson RE, Kristal AR, et al. Stages of change in adopting healthy diets: fat, fiber and correlates of nutrient intake. Health Educ Q 1994;21(4):499-519.

[18] Hildebrand DA, Betts NM. Assessment of stage of change, decisional balance, self-efficacy and use of processes of change of low-income parents for increasing servings of fruits and vegetables to preschool-aged children. J Nutr Educ Behav 2009;41(2):110-9.

[19] Bawadi HA. Applying the Transtheoretical model to promote greater fruit and vegetable consumption: a successful approach to maintaining behavioral change: (PhD Thesis): Louisiana State University: 2004.

[20] Di Carmo FM. Examining the application of the Transtheoretical model of change for fruit and vegetable consumption among college students. $\mathrm{PhD}$ thesis): Colorado State University Pro Quest: 2002.

[21] Prochaska J0, Johnson S, Lee P. The Transtheoretical model of behavior change. In: Shumaker SA, Ockene JK, Riekert KA. eds. The handbook of health behavior change. New York: Springer Publishing Company 2009:59-83.

[22] Hildebrand DA. Assessment of stage of change for increasing fruit and vegetable availability and accessibility in low-income family with preschool-age children: (PhD Thesis): Oklahoma State University, UMI: Pro-Quest Company 2004.

[23] Kim YH. Adolescents' smoking behavior and its relationships with psychological constructs based on transtheoretical model: a cross-sectional survey. Int J Nurs Stud 2006;43(4):439-46. 